\title{
Електронний бізнес: переваги та ризики в період цифрової трансформації
}

\begin{abstract}
У статті обтрунтовано доцільність створення, ведення та розвитку електронного бізнесу як актуальної бізнес-моделі в період циифрової трансформації. Авторами пропонується підхід до визначення електронного бізнесу як різновиду економічної діяльності, коли для успішної реалізачії бізнес-процесів активно використовуються інформачійно-комунікачійні технології та мережі.

Існують різні базові можливості для старту електронного бізнесу. У загальному вигляді ключові напрями ведення електронного бізнесу передбачають початкове створення підприємства, яке надає послуги виключно за допомогою використання інформаційнокомунікаційних технологій та мереж, доповнення традиційних послуг електронними вже діючим підприємством (з подальшим виділенням такого виду діяльності в окремий напрям бізнесу) та поступовий перехід підприємства до ведення електронного бізнесу. До безумовних переваг ведення електронного бізнесу з використанням мережевих технологій у господарській діяльності підприємств варто зарахувати: прискорення обслуговування клієнтів, усунення обмежень щцодо розташування торгових площ, магазинів, офісів та доступність для клієнтів, підтримання бізнесу в актуальному стані й орієнтування на удосконалення бізнес-процесів.

За результатами проведеного дослідження було ідентифіковано ряд ризиків, пов'язаних із веденням електронного бізнесу, основними з яких є: ризики мережевої безпеки, ризики провалів у маркетингу, ризики прихованих витрат (або витрат на обслуговування і модернізацію), бізнесризики (ділові ризики), ризики шахрайських дій, наприклад, з викраденими банківськими картками та ін. В иілому, розуміння ризиків електронного бізнесу необхідне для визначення підходу підприємства до управління цими ризиками, зокрема адекватності системи внутрішнього контролю. Така система може містити інфраструктуру захищеності та пов'язані із ичим заходи контролю. Неврахування фактора ризику може призвести до зниження загального очікуваного результату з різними наслідками. Серед таких наслідків можуть бути: порушення життєздатності бізнесу, втрата конкурентних переваг, погіршення ділового іміджу та фінансової стабільності, зменшення сукупної економічної вигоди, додаткових витрат фінансового та нефінансового характеру тощзо.
\end{abstract}

Ключові слова: бізнес-прочеси; управління бізнес-процесами; електронний бізнес; иңифрова трансформація; ризики електронного бізнесу.

Актуальність теми. Останніми роками у всьому світі спостерігається нарощення обсягів електронної торгівлі, що пов'язано із розвитком інтернет-технологій та глобальною цифровізацією всіх бізнес-процесів. Крім того, цей процес прискорює впровадження карантинних обмежень, пов'язаних 3 перешкоджанням розповсюдження пандемії COVID-19.

Цифрова трансформація бізнес-процесів стимулює власників підприємств перевести частину свого бізнесу в електронний формат. Електронний бізнес - це відносно новий підхід до задоволення потреб споживачів, впровадження нових продуктів і розширення географічних кордонів, таких як океани і гори. Незважаючи на те, що у цій новій бізнес-моделі, яка впроваджується швидкими темпами, є багато позитивних аспектів, наявні ризики можуть стати серйозною проблемою для всього електронного бізнесу та значною мірою впливати на розмір чистого прибутку підприємств.

Аналіз останніх досліджень і публікацій, на які спираються автори. Нині як за кордоном, так і в нашій країні накопичено вагомий теоретико-методологічний потенціал та досвід у галузі дослідження електронного бізнесу. У цьому аспекті необхідно виокремити праці таких зарубіжних вчених, як С.Белінг, В.Т. Ван, О.Вітез, І.Грозний, Н.Далевська, Е.Донтігні, А.Квілінські, Д.Коппола, П.Лейк, Е.Р. Лю. Проблемам розвитку електронного бізнесу, управління персоналом в електронній комерції, а також розвитку цифрових навичок для забезпечення конкурентоспроможності персоналу в умовах цифрової економіки присвячено наукові праці вітчизняних учених: В.В. Бондарчука, Т.В. Бочулі, К.Х. Герасимюка, О.Коваленко, М.Макарової, С.В. Обіход, Д.С. Пілевича, К.В. Шиманської та ін. Зокрема, В.В. Бондарчук і К.В. Шиманська при дослідженні напрямів цифрової економіки пов'язують ії подальший розвиток 3 більш активним впровадженням, насамперед малим і середнім бізнесом, інформаційних технологій. Це в свою чергу вимагає від підприємств динамічного розвитку цифрових 
навичок персоналу. Наразі ж, на думку авторів, спостерігається низький рівень використання хмарних сервісів, примітивний цифровий функціонал сайтів переважної частини представників малого бізнесу, а також нерозуміння пересічними представниками бізнесу цінності накопичення даних $\mathrm{i}$ шляхів їх монетизації [6, с. 18].

Велику увагу ризикам електронного бізнесу в своїх працях приділяють С.Белінг, О.Вітез, К.Х. Герасимюк, М.Макарова, Е.Донтігні та П.Лейк. Так К.Х. Герасимюк вважає, що перехід практично всіх сфер діяльності людства у віртуальний простір, в тому числі через світову пандемію, міжнародні коливання економіки тощо, спонукає бізнес до покращення системи кібер- та інформаційної безпеки. За цих умов автор пропонує до врахування ризики розповсюдження і захисту інформації, що включають [2, c. 36]: тотальну діджиталізацію інформації, іiі обіг, зберігання; загрозу неналежного використання та зміни або пошкодження інформації; несанкціоноване втручання в інформаційну систему підприємства ззовні. Тому підприємства потребують вироблення дієвих механізмів управління цими ризиками й у першу чергу механізмів кібер- та інформаційної безпеки. В свою чергу С.Белінг і П.Лейк вбачають необхідність врахування під час визначення ризиків ймовірності шахрайських дій з боку клієнтів [10]. Особливо поширеними вони $€$ в електронній комерції. Разом із тим залишаються відносно малодослідженими вектори розвитку електронного бізнесу та перспективи, які вони дають.

Метою статті $є$ визначення напрямів ведення електронного бізнесу, а також виявлення переваг i ризиків його розвитку в умовах цифрової трансформації.

Викладення основного матеріалу. Електронний бізнес отримує все більшого поширення в економіці і позиціонується як нова бізнес-модель, яка має поступово замінити усі існуючі. Сьогодні електронний бізнес доцільно трактувати як різновид економічної діяльності, що проводиться 3 використанням інформаційно-комунікаційних технологій та мереж у реалізації бізнес-процесів 3 метою отримання прибутку. Його визначальною рисою $є$ використання інформаційно-комунікаційних, мережних і хмарних технологій [4, с. 156].

Багато науковців вважає, що єдина відмінність між електронним бізнесом та офлайн-бізнесом (традиційним бізнесом) полягає у використанні інформаційно-комунікаційних технологій в управлінні бізнес-процесами, які не значно впливають на відносини між підприємством і його клієнтами. На думку А.Квілінські, головною особливістю електронного бізнесу є використання нових форм взаємодії між учасниками господарських операцій, відмінних від тих, що мали перевагу в бізнесі раніше [9].

Завдяки сформованій моделі стимулювання розвитку електронного бізнесу «Країна - бізнес технології - уряд» (CBTG), що враховує вплив зовнішнього середовища на підприємства, які займаються електронним бізнесом, були визначені пріоритетні фактори впливу на розвиток електронного бізнесу в різних країнах [13]. Згідно з дослідженням, на розвиток електронного бізнесу найбільше впливає технологічний рівень розвитку країни; друге і третє місця посідають загальні особливості країни та стан бізнес-середовища [9]. Крім того, сьогодні не можна залишити поза увагою фактор пандемії COVID-19. Так з часу введення обмежень для бізнесу, пов'язаних з боротьбою 3 епідемією, частка електронної комерції в загальному обсязі роздрібної торгівлі суттєво збільшилася (рис. 1) [7].

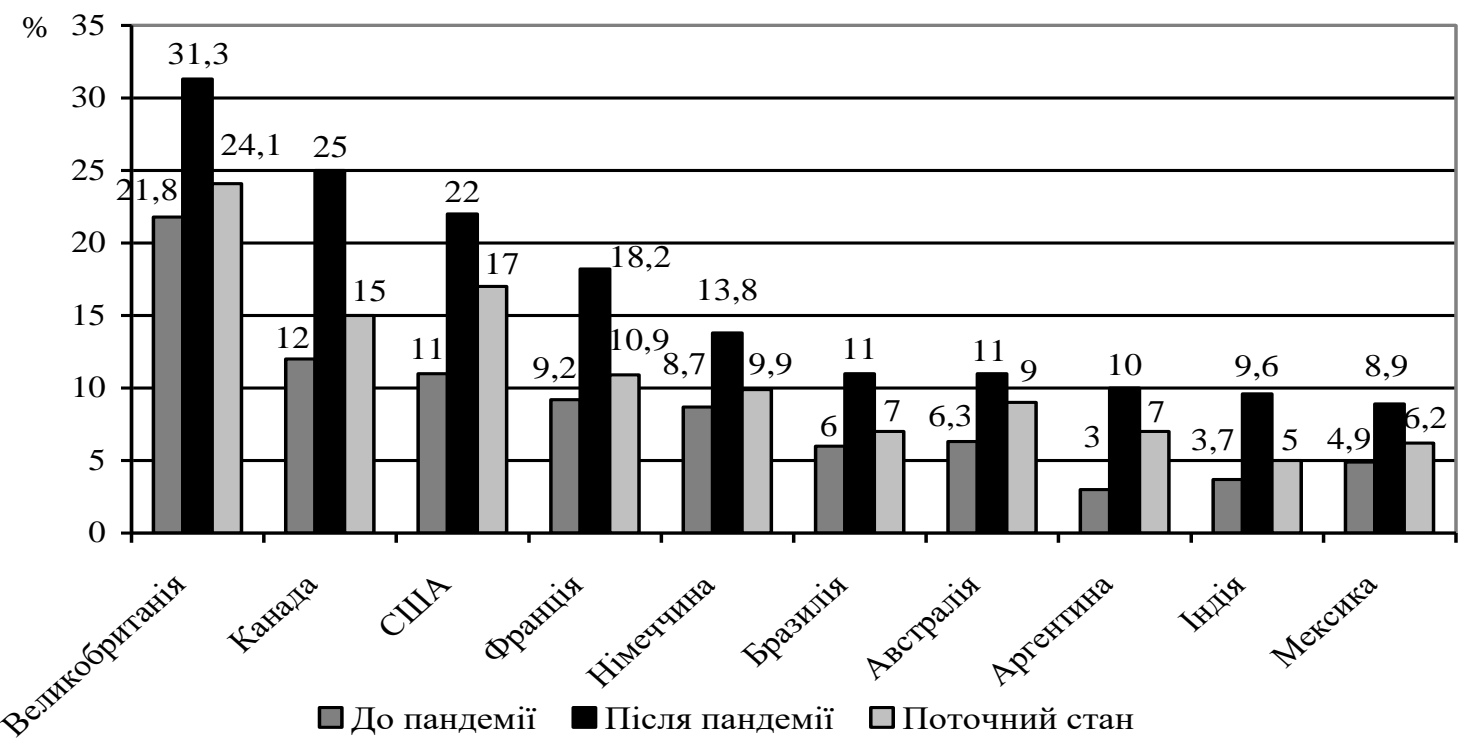

Рис. 1. Частка електронної комериії у загальному обсязі роздрібної торгівлі в окремих країнах світу до та після пандемії COVID-19 
Виняток становлять ті види діяльності, що передбачають перетин кордону, який нині ускладнений через карантинні обмеження, наприклад, туризм, міжнародна логістика. Фінансові та торгові транзакції, які проводяться в межах цих видів бізнесу за допомогою комп'ютерних мереж, та бізнес-процеси, пов'язані з проведенням цих транзакцій, свідчать про зменшення обсягу доходів підприємств. Сьогодні до основних напрямів ведення електронного бізнесу можна зарахувати такі види діяльності [5, с. 69]:

1. Створення підприємства, яке надає послуги тільки за допомогою використання інформаційнокомунікаційних технологій та можливостей (наприклад, пропускної спроможності) мереж. До особливостей функціонування такого підприємства належать: відсутність фізичних відділень, структурних підрозділів, які безпосередньо взаємодіють із клієнтами під час виконання основного виду діяльності; наявність фізичних складів, центрів, які використовуються для надання послуг (не завжди, особливо для фінансових компаній, що надають послуги онлайн); існування центрального офісу; наявність значного штату IT-спеціалістів; формування креативного середовища для роботи працівників; наявність ефективного каналу комунікації з клієнтами за допомогою телефонних дзвінків; проведення масштабних маркетингових заходів у мережі та ін.;

2. Доповнення переліку традиційних послуг електронними вже діючим підприємством 3 подальшим виділенням такого виду діяльності в окремий напрям бізнесу. До особливостей створення такого електронного бізнесу варто зарахувати: наявність у структурі підприємства фізичних структурних підрозділів, існування прямого контакту між виробниками та споживачами товарів (переважно, але не обов'язково), штат складається не лише із ІТ-спеціалістів, але й інших категорій працівників; поступовий розвиток електронного бізнесу паралельно з основним; тривалі процедури спрощення різних бізнеспроцесів за допомогою впровадження нових інформаційних технологій на різних етапах виробництва та продажу товарів (надання послуг); поєднання переваг ведення традиційного й електронного бізнесу, що дозволяє забезпечити якісні умови обслуговування клієнтів;

3. Поступовий перехід підприємства до ведення лише електронного бізнесу. До особливостей створення такого електронного бізнесу належать такі: еволюційний шлях трансформації способу ведення підприємницької діяльності; обмеженість використання, оскільки не всі види бізнесу можна повністю перевести в електронний режим; значні трансформаційні процеси в здійсненні господарської діяльності, які вимагають зміни структури підприємства, персоналу, стандартів надання послуг (продажу товарів); відбувається зміна логотипів, символіки підприємства, здійснюється ребрендинг тощо.

Використання мережевих технологій у господарській діяльності підприємств зумовлене значними перевагами, які дає електронний бізнес у результаті їх впровадження. Зокрема, на думку Г.Тан, до переваг електронного бізнесу сьогодні варто зарахувати [11]:

1. Усунення обмежень щодо розташування торгових площ, магазинів, офісів тощо та доступність для клієнтів (споживачів). Так Інтернет охоплює весь світ і, отже, всі часові пояси. Це означає, що коли підприємства проводять свою діяльність в Інтернеті, вони мають однакові можливості. У випадку 3 фізичним магазином (офісом та ін.) клієнти обмежені тим, наскільки близько магазин знаходиться від їх поточного місця перебування та його годинами роботи. Електронні підприємства, 3 іншого боку, доступні з будь-якого місця, де є доступ до мережі, та відкриті цілодобово. Крім того, в міру розвитку мобільної комерції (m-commerce), електронний бізнес отримує ще одну важливу перевагу: бути доступним для всіх, хто має мобільний пристрій (смартфон або планшет з технологією LTE). Клієнти будуть обмежені лише покриттям мобільної мережі свого оператора;

2. Скорочення витрат часу і коштів. Через рахунки за оренду приміщень, оплату комунальних послуг, послуг мобільного зв'язку та загальне утримання фізичного офісу витрати власника постійно збільшуються. У той же час, розміщуючи свій бізнес в Інтернеті, власник суттєво зменшує або повністю усуває більшість з них. Крім того, все стає набагато простіше з точки зору логістики, оскільки одна людина може виконувати роботу кількох людей. Візьмемо, наприклад, масове спілкування 3 клієнтами. Зробити масову розсилку листів клієнтам за допомогою електронної пошти набагато ефективніше, ніж надіслати 100 прямих листів (поштових відправлень) адресатам. На додаток до процесів, спрямованих на клієнтів, внутрішні процеси також стають більш зручними в електронній книжці під час виходу в Інтернет. Наприклад, витрати на транзакції зменшуються, оскільки немає необхідності наймати касира, коли програмне забезпечення кошика для покупок дозволяє клієнтам самостійно оформляти замовлення. I якщо цього недостатньо, маркетинг електронного бізнесу також є більш доступним, оскільки реклама в Інтернеті обходиться дешевше, ніж у разі використання традиційних маркетингових каналів;

3. Прискорення обслуговування клієнтів. Коли клієнти звертаються до персоналу підприємства, вони хочуть отримати максимально швидкі, але такі ж компетентні відповіді. Завдяки можливостям електронної пошти та онлайн-чатів підприємства не мають жодних проблем із задоволенням цих потреб. Крім того, ці гнучкі форми обслуговування клієнтів можуть надаватися і після завершення годин роботи фізичного офісу (магазину). Електронний бізнес також забезпечує можливість оформити зручну доставку товарів (продуктів) прямо до вхідних дверей клієнта, тому замовникам навіть не потрібно моніторити трафік на дорогах і покірно стояти у заторах; 
4. Орієнтування на удосконалення бізнес-процесів. Коли справа доходить до того, щоб дізнатися більше про своїх клієнтів, власники фізичних офісів (магазинів) не можуть стати на один рівень 3 підприємствами, що займаються електронним бізнесом. За допомогою таких інструментів, як Google Analytics, набагато легше отримати доступ до інформації про продажі та клієнтів без додаткових витрат. $€$ потреба дізнатися, як просувався товар в останні три місяці, або скільки постійних клієнтів було серед замовників? Якщо персонал займається традиційним обліком у звичайному фізичному офісі (магазині), у нього фактично немає легкого доступу до таких даних. Разом із тим, ці дані дають уявлення про купівельну поведінку та інтереси клієнтів підприємства, що є необхідним для покращення бізнесу;

5. Підтримання бізнесу в актуальному стані. Відкриття електронного бізнесу дозволяє власнику бути в курсі того, що відбувається в даний час: він вирівнює умови гри і дає підприємству ресурси, необхідні для утримання конкурентних позицій на сучасному все більш цифровому ринку. Наприклад, присутність підприсмства в популярних соціальних мережах - це великий резерв для поширення бренда підприємства. Щоб залишатися актуальними, підприємствам необхідно постійно публікувати доречний контент у цих місцях, рекламувати останні новинки серед товарів і послуг, проводити різні конкурси для цільової аудиторії.

Як бачимо, перебування в Інтернеті робить бізнес більш зручним, доступним і готовим до надання інформаційної допомоги або консультацій своїм клієнтам. Такий бізнес насправді зосереджений на тому, щоб приносити користь своїм клієнтам. Разом із тим, стають більш прозорими і зрозумілими для подальшого розбору аналітиками поточні бізнес-процеси підприємства.

Отже, електронний бізнес може забезпечити конкретні переваги підприємствам, пов'язані 3 охопленням більш широкої клієнтської бази, проведенням швидших транзакцій тощо. Клієнти часто звертаються до Інтернету, щоб знайти потрібні магазини або постачальників товарів і послуг. І якщо до цього додати ще той факт, що переведення традиційного бізнесу в електронний не потребує від власника значних вкладень коштів і ним не важко займатися, то складається враження, що моделі електронного бізнесу є безпроблемним способом вирішення ділових і фінансових проблем [8]. Однак, перш ніж переводити всі бізнес-процеси підприємства у цифровий вимір, власникам бізнесу необхідно знати всі можливі ризики (рис. 2).

Проведений огляд літературних та електронних джерел, в тому числі корпоративних порталів, свідчить про існування різних підходів вчених до класифікації ризиків електронного бізнесу. Зокрема, серед ризиків розвитку електронного бізнесу О.Вітез вирізняє [12]:

- систематичні ризики, тобто ризики, з якими підприємство зіштовхується на всьому ринку або в сегменті ринку, на якому воно працює. Класичним прикладом систематичних ризиків на ринку електронного бізнесу є крах дотком-компаній (компаній, чия бізнес-модель заснована на роботі в мережі Інтернет) в 2000-2001 роках. Так декілька представників електронного бізнесу, які розпочали свою діяльність і стали публічними, після цього були придбані іншими підприємствами. Більшість таких підприємств мали невеликий грошовий потік і не могли отримати прибуток; ці компанії цінували ріст більше фінансової стабільності, створюючи нестійкий «економічний міхур», який лопнув, знищивши багато доткомів. Хоча цей вид систематичних ризиків може більше не повторюватися, більшість сегментів ринку може працювати у межах бізнес-циклу - рости, виходити на плато і скорочувати свою діяльність. Власники та керівники підприємств, які займаються електронним бізнесом, повинні мати можливість оцінити свій сегмент ринку та спланувати кожен етап бізнес-циклу;

- ризики мережевої безпеки, тобто електронний бізнес стикається з багатьма різними видами ризиків, пов'язаних із безпекою бізнес-інформації та інформації про клієнтів. Зокрема, комп’ютерні віруси та кіберзлочинці (хакери) постійно намагаються проникнути в онлайн-компанії та викрасти персональні дані клієнтів і фінансову інформацію. Ці ризики безпеки змушують електронний бізнес використовувати програмне забезпечення та коди шифрування, які обмежують здатність сторонніх осіб зламати їхні системи. Ризики мережевої безпеки також можуть призвести до юридичних проблем для електронного бізнесу, оскільки підприємства зобов'язані захищати інформацію про клієнтів. Порушення в системі електронного бізнесу також збільшує страховий ризик підприємства, оскільки страховики вимагають більш високих внесків для компаній з «юридичними нюансами», якщо вони, як їх клієнти, вирішать зайнятися електронним бізнесом;

- бізнес-ризики (ділові ризики) - підприємницькі ризики, пов'язані із ризиками, 3 якими підприємства зіштовхуються при щоденному веденні господарських операцій. Ці ризики враховують проблеми із запасами, персоналом, накладними витратами або ланцюгами поставок. Оскільки електронний бізнес не потребує значних місць розташування або складів, він має покладатися на ланцюг поставок, щоб забезпечити своєчасну доставку товарів до клієнтів (споживачів). Кожного разу, коли під час розподілу товарів підприємству доводиться покладатися на фізичних осіб або інші підприємства, ймовірність виникнення таких ризиків може зрости. Ділові ризики також виникають, якщо електронний бізнес не може закупити в достатній кількості товарно-матеріальні запаси і швидко та ефективно переміщати їх по ланцюгу поставок. 


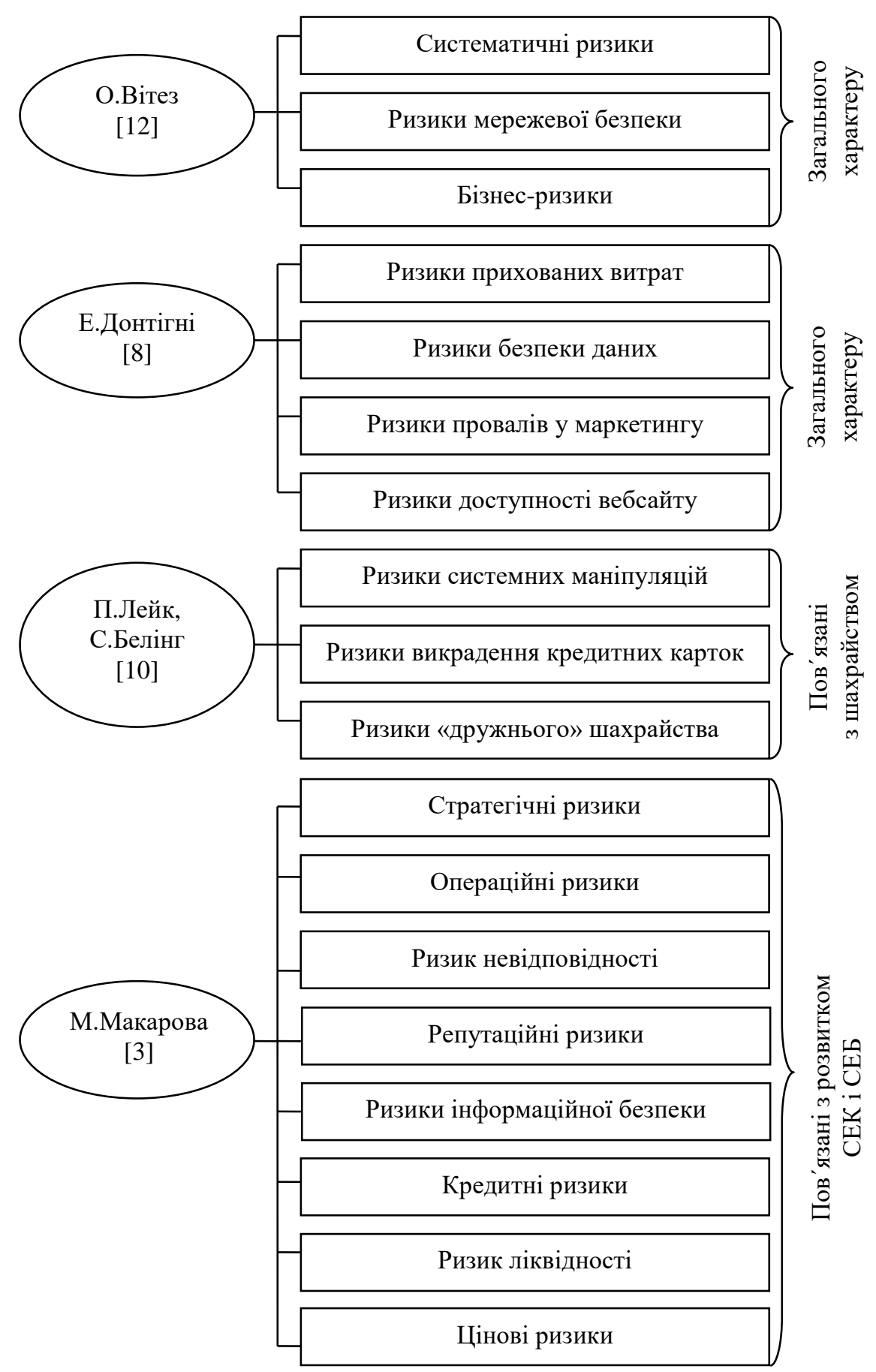

Рис. 2. Систематизацуія поглядів вчених на можливі ризики електронного бізнесу

Донтігні Е. виокремлює ризики прихованих витрат (або витрат на обслуговування і модернізацію), ризики безпеки даних, ризики провалів у маркетингу та ризики доступності вебсайту [8]. Зазначимо, що одним із найголовніших аргументів на користь електронного бізнесу $є$ низькі початкові затрати діяльності. Для прикладу, доменні імена та вебхостинг передбачають порівняно невеликі затрати, ніж оренда чи купівля фізичного простору (приміщення для офісу). В той час як деякі власники бізнесу займаються створенням вебсайту власноруч, багато хто для цього наймає сторонніх розробників. В цілому вартість комерційного сайту може вимірюватися тисячами доларів. Планове обслуговування та оновлення (крім того, модернізація) вебсайту також потребує часу, що може означати або наймання когось ззовні для виконання цієї роботи, або використання власних ресурсів. У будь-якому разі власник ризикує витратити додаткові кошти на вирішення цих питань.

Звичайно кожен бізнес зіштовхується 3 проблемами безпеки даних, i електронний бізнес максимально поглиблює ці проблеми. Клієнти вводять на вебсайт значну кількість конфіденційної 
інформації (персональних даних) - від номерів телефонів до номерів кредитних карток. Власник сайту бере на себе відповідальність за захист цієї інформації за допомогою всіх наявних засобів безпеки, таких як шифрування Secure Sockets Layer або укладання угод з третіми сторонами щодо безпечної обробки транзакцій. Порушення безпеки даних - це серйозний ризик для підприємства, оскільки загрожує власнику штрафами, а також втратою довіри з боку клієнтів.

I онлайн-, i офлайн-бізнес покладаються на ефективний маркетинг для стимулювання росту i продажів. На жаль, методи і стратегії онлайн-маркетингу сильно відрізняються від офлайн-методів. Власники бізнесу можуть заплутатися в SMO i SMM, вірусних технологіях і соціальних мережах, ризикуючи провалити маркетинг. Підприємства, які погано знайомі 3 електронним бізнесом, можуть вирішити найняти фахівця або компанію, що спеціалізується на онлайн-маркетингу, в додаток до будьяких офлайн-маркетингових послуг, які вони вже використовують. Таким чином, без ефективного онлайн-маркетингу, спрямованого на приведення відвідувачів на вебсайт, увесь проєкт може обернутися марною тратою часу та фінансових ресурсів.

I нарешті, навіть якщо власник керує доходами, застосовує найсучасніші технології захисту даних $\mathrm{i}$ передові методи онлайн-маркетингу, недосконала служба вебхостингу може зруйнувати його електронний бізнес. Сьогодні жоден вебхостинг не може гарантувати, що вебсайт постійно буде доступний. Все, від збою сервера до недостатньої пропускної здатності, призводить до падіння вебсайтів. Відтак підприємства, яким надають погані послуги хостингу, постійно втрачають зв'язок зі своїми сайтами. Клієнти, які регулярно помічають, що комерційний сайт недоступний, невдовзі перестануть на нього заходити. Цієї проблеми можна уникнути, якщо звертатися за послугами до перевірених авторитетних хостинг-провайдерів.

Інший підхід щодо обгрунтування та класифікації ризиків електронного бізнесу наводить М.В. Макарова. Так вчена до ризиків, які породжуються невизначеністю та конфліктністю під час розвитку систем електронної комерції (СЕК) та електронного бізнесу (СЕБ), зараховує [3, с. 40-42]:

- стратегічні ризики - помилковість у виборі системи віддаленого обслуговування клієнтів призводить до низького ступеня іï інтеграції з інформаційною системою підприємства, робить систему електронної комерції підприємства невиправдано дорогою. Без стратегії розвитку та планування складно вчасно приділяти увагу аспектам інформаційної безпеки і внаслідок цього реагувати на загрози відповідно до процесу ризику, що робить стратегічні ризики найбільш небезпечними серед усіх;

- операційні ризики - виникають під час поточного функціонування СЕК і СЕБ; це ризики прямих і непрямих втрат, що викликані помилками або недосконалістю процесів у цих системах, помилками або недостатньою кваліфікацією персоналу підприємства, несприятливими зовнішніми подіями нефінансової природи, наприклад, шахрайством або стихійним лихом. На думку М.В. Макарової, операційні ризики містять: ризик персоналу; ризик процесу; ризик технологій; ризик середовища та ризик фізичного втручання у діяльність систем;

- ризик невідповідності - наявність СЕК і СЕБ на підприємстві потребує додаткової відповідності вимогам чинного законодавства та державних регуляторів фінансових транзакцій i обробки персональних даних, зокрема тих, що відповідають вимогам інформаційної безпеки;

- репутаційні ризики - клієнти болісно ставляться до неякісної роботи СЕК і СЕБ, що може виявлятися у тимчасовому обмеженні переліку заявлених онлайн-послуг, доступу до них або низькій стійкості СЕК і СЕБ. Це може викликати у клієнтів негативне ставлення до підприємства в цілому;

- ризики інформаційної безпеки є частиною операційних ризиків. Наявність СЕК і СЕБ привертає увагу кіберзлочинців, в арсеналі яких $є$ широкий і постійно обновлюваний набір технологічного інструментарію для несанкціонованого доступу. Проявами таких ризиків є ризики зламування засобів криптозахисту, атаки на бази даних електронних торговельних систем, витік конфіденційної інформації;

- кредитні ризики - загрози, які можуть виникнути під час кредитування через Інтернет та пов'язані 3 ідентифікацією клієнта, перевіркою його кредитоспроможності, достовірністю одержуваних відомостей, забезпеченням конфіденційності переданої інформації тощо;

- ризик ліквідності - СЕК і СЕБ дозволяють значно розширити базу кліснтів. Разом із тим, завдяки Інтернету клієнти здатні легко порівнювати різні пропозиції і, виявивши найбільш вигідну, масово «переходити» від одного підприємства до іншого. Така можливість загострює конкуренцію на ринку торговельних і банківських послуг та створює для кожного підприємства загрозу кризи ліквідності;

- цінові ризики - можливість проводити за допомогою СЕК і СЕБ операції з цінними паперами або валютою роблять доступною спекулятивну діяльність, в тому числі із застосуванням спеціальних технічних засобів.

П.Лейк і С.Белінг зауважують, що електронний бізнес стикається з багатьма проблемами, особливо в сучасній турбулентній економіці, а втрати, спричинені шахрайством, ще більше ускладнюють прибутковість та виживання бізнесу. Шахрайство може бути скоєне ким завгодно, воно може варіюватися від клієнтів, які використовують як примітивні способи обману, так і більш витончені схеми 
відмивання грошей. У зв'язку з цим науковці проводять класифікацію видів шахрайства, які впливають на появу ризиків в електронному бізнесі, і виокремлюють [10, с. 280-281]:

- системні маніпуляції - багато 3 шахрайських дій, які мають місце в традиційному бізнесі, можуть бути застосовані і щодо електронного бізнесу. Фальшиві рахунки, помилкові коригування інвентаря та маніпуляції з коштами - ось лише деякі з видів діяльності, які люблять використовувати шахраї. Цей вид шахрайства має набагато більш технічний характер на відміну від використання викрадених кредитних карток або повернення інших товарів, ніж ті, які були взяті в кредит, однак це серйозна проблема для електронного бізнесу;

- викрадені кредитні картки - це один із видів шахрайства, з яким сьогодні зіштовхується електронний бізнес; він полягає в тому, що злочинці використовують чужі кредитні картки для придбання товарів. Шахрайство, скоєне злочинцями в Інтернеті, часто пов'язують з особами, які проживають у країнах третього світу, де уряди, закони та ділова практика по суті надають широку арену для здійснення шахрайських дій;

- «дружнє» шахрайство - описує споживачів, які купують товари або послуги в Інтернеті за допомогою власних кредитних карток, зрештою, отримують їх, а потім здійснюють повернення коштів безпосередньо через постачальника картки. Шахраї в електронному бізнесі можуть оскаржувати онлайнзамовлення, але при цьому не повертатимуть одержані товари. Коли відбувається повернення платежу, продавець завжди несе відповідальність (з точки зору емітента карти), і проблема для продавця полягає в тому, що немає можливості перевірити справжність транзакції. Втім продавці, які продають послуги, можуть створити систему для перевірки повернення платежу, і в разі його виникнення, вони можуть негайно призупинити надання послуг.

Тут маємо зазначити, що, на нашу думку, наведена класифікація видів шахрайства більше притаманна саме електронній комерції, яка є однією зі складових електронного бізнесу.

В цілому розуміння ризиків, пов'язаних із веденням електронного бізнесу, необхідне для визначення підходу підприємства до управління цими ризиками, зокрема адекватності системи внутрішнього контролю, враховуючи інфраструктуру захищеності та пов'язані із цим заходи контролю. Відтак перед управлінцями сучасних підприємств постає завдання ідентифікації та оцінювання ризиків 3 метою іх усунення або мінімізації. Адже, як підкреслює Т.В. Бочуля, модель бізнес-розвитку, що не враховує фактор ризику, неодмінно призведе до зниження загального очікуваного результату з різними наслідками, зокрема, до порушення життєздатності бізнесу, втрати конкурентних переваг, погіршення ділового іміджу, фінансової нестабільності, зменшення сукупної економічної вигоди, додаткових витрат фінансового та нефінансового характеру та ін. [1, с. 277].

Таким чином, обгрунтована система управління ризиками у сфері електронного бізнесу здатна забезпечити ефективне досягнення цілей суб'єктом господарювання і відкрити можливості для його подальшої діяльності. Заходи щодо управління ризиками в сфері електронного бізнесу мають запроваджуватися як на рівні держави, так i на рівні окремих підприємств. Так для подолання глобальних зовнішніх ризиків, пов'язаних, наприклад, із злочинними діями кібершахраїв щодо викрадення персональних даних та бізнес-інформації, має бути створено відповідне нормативно-правове поле та дієва система державних контролюючих органів. На рівні окремих підприємств мають бути розроблені та впроваджені обгрунтовані заходи управління різними ризиками за умови їх виникнення, а також створені відповідні служби інформаційної безпеки. Окрім цього, аналітичними службами або керівництвом повинен проводитися аналіз, вимірювання та ранжування ризиків за ступенем небезпечності та впливу на результати діяльності підприємства з метою створення якісного аналітичного забезпечення для прийняття обгрунтованих управлінських рішень у майбутньому.

Висновки та перспективи подальших досліджень. Переведення бізнес-процесів у цифровий вимір видається досить перспективним напрямом розвитку бізнесу навіть в умовах сьогоднішньої турбулентної економіки. Використання інформаційно-комп'ютерних технологій і можливостей мережі в бізнесі дозволяє охопити більше клієнтів і покращити їх обслуговування, проводити значно швидші та більш безпечні транзакції, уникнути проблем фізичного розміщення офісів та обмеженого графіку роботи. Насправді, електронний бізнес забезпечує цілий ряд переваг перед традиційним способом ведення господарської діяльності, але й він не позбавлений типових підприємницьких ризиків. Щоправда, у випадку електронного бізнесу до них ще додаються ризики, пов'язані 3 шахрайськими діями 3 персональними даними та бізнес-інформацією, з розвитком СЕК і СЕБ та ін. У зв'язку з цим у сфері електронного бізнесу необхідно застосовувати обгрунтовану систему управління ризиками, що здатна забезпечити ефективне досягнення цілей підприємством і відкрити можливості для його успішної діяльності. Подальші дослідження вбачається проводити в напрямі дослідження управління ризиками електронного бізнесу. 
Список використаної літератури:

1. Бочуля Т.В. Інновативний розвиток обліково-аналітичного забезпечення управління підприємством : монографія / Т.В. Бочуля. - Х. : ВД «ІНЖЕК», 2015. - 404 с.

2. Герасимюк K.X. Механізми державного управління кібер- та інформаційною безпекою: проблеми та шляхи вирішення / К.X. Герасимюк // Економіка, управління та адміністрування. - 2021. - Вип. 3 (97). - С. 36-40.

3. Макарова М.В. Розвиток систем електронної комерції та електронного бізнесу в умовах невизначеності та ризику / М.В. Макарова // Економіко-математичне моделювання соціально-економічних систем : зб. наук. праць. - К. : Міжнародний науково-навчальний центр інформаційних систем і технологій НАН України та МОН України, 2016. - Вип. 21. - С. 34-68.

4. Обіход С.В. Особливості управління персоналом в електронній комерції / С.В. Обіход, В.О. Ткачук, O.M. Омельчук // Інфраструктура ринку : електрон. фахов. наук.-практ. журнал. - 2020. - Вип. 50. - С. 155160 [Електронний ресурс]. - Режим доступу : http://www.market-infr.od.ua/uk/50-2020.

5. Пілевич Д.С. Теоретичне підгрунтя розвитку електронного бізнесу / Д.С. Пілевич // Бізнес Інформ. - 2019. № 5. - C. 67-72.

6. Шиманська K.B. Пріоритетні напрями та механізми розвитку цифрової економіки в Україні / К.В. Шиманська, В.В.Бондарчук // Економіка, управління та адміністрування. - Житомир, 2021. Вип. 1 (95). - С. 17-22.

7. Coppola D. E-commerce worldwide - statistics \& facts / D.Coppola [Electronic resource]. - Access mode : https://www.statista.com/topics/871/online-shopping/\#dossier-chapter1.

8. Dontigney E. Risks of E-Business / E.Dontigney [Electronic resource]. - Access mode : https://yourbusiness.azcentral.com/advantages-online-retailing-sales-channels-12635.html.

9. Formation of the entrepreneurship model of e-business in the context of the introduction of information and communication technologies / A.Kwilinski, N.Dalevska, S.Kravchenko et al. // Journal of Entrepreneurship Education. 2019. - Vol. 22, Special Issue 1 [Electronic resource]. - Access mode : https://www.abacademies.org/articles/Formationof-the-entrepreneurship-model-of-e-business-1528-2651-22-S1-337.pdf.

10. Lake P. E-businesses at risk: a look at the impact and control of e-business fraud / P.Lake, S.Behling // Issues in Information Systems. - 2010. - Vol. XI, № 1. - P. 280-285.

11. Tan G. E-business and its advantages / G.Tan [Electronic resource]. - Access mode : https://www.volusion.com/blog/e-business-advantages/.

12. Vitez $O$. E-business risks / O.Vitez [Electronic resource]. - Access mode : https://bizfluent.com/list-6188289-ebusiness-risks.html.

13. Wang W.T. The stickiness intention of group-buying websites: The integration of the commitment - trust theory and e-commerce success model / W.T. Wang, Y.S. Wang, E.R. Liu // Information \& Management. - 2016. № 53 (5). - P. 625-642.

\section{References:}

1. Bochulja, T.V. (2015), Innovatyvnyj rozvytok oblikovo-analitychnogo zabezpechennja upravlinnja pidpryjemstvom, monografija, VD «INZhEK», Harkiv, 404 p.

2. Gerasymjuk, K.H. (2021), «Mehanizmy derzhavnogo upravlinnja kiber- ta informacijnoju bezpekoju: problemy ta shljahy vyrishennja», Ekonomika, upravlinnja ta administruvannja, Issue 3 (97), pp. 36-40.

3. Makarova, M.V. (2016), «Rozvytok system elektronnoi' komercii' ta elektronnogo biznesu v umovah nevyznachenosti ta ryzyku», Ekonomiko-matematychne modeljuvannja social'no-ekonomichnyh system, zb. nauk. prac', Mizhnarodnyj naukovo-navchal'nyj centr informacijnyh system i tehnologij NAN Ukrai'ny ta MON Ukrai'ny, K., Issue 21, pp. 34-68.

4. Obihod, S.V., Tkachuk, V.O. and Omel'chuk, O.M. (2020), «Osoblyvosti upravlinnja personalom v elektronnij komercii'», Infrastruktura rynku, elektron. fahov. nauk.-prakt. zhurnal, Issue 50, pp. 155-160, [Online], available at: http://www.market-infr.od.ua/uk/50-2020

5. Pilevych, D.S. (2019), «Teoretychne pidg'runtja rozvytku elektronnogo biznesu», Biznes Inform, No. 5, pp. 67-72.

6. Shymans'ka, K.V. and Bondarchuk, V.V. (2021), «Priorytetni naprjamy ta mehanizmy rozvytku cyfrovoi' ekonomiky v Ukrai'ni», Ekonomika, upravlinnja ta administruvannja, Zhytomyr, Issue 1 (95), pp. 17-22.

7. Coppola, D. (2021), «E-commerce worldwide - statistics \& facts», [Online], available at: https://www.statista.com/topics/871/online-shopping/\#dossier-chapter1

8. Dontigney, E. (2019), «Risks of E-Business», [Online], available at : https://yourbusiness.azcentral.com/advantages-online-retailing-sales-channels-12635.html

9. Kwilinski, A., Dalevska, N., Kravchenko, S. et al (2019), «Formation of the entrepreneurship model of e-business in the context of the introduction of information and communication technologies», Journal of Entrepreneurship Education, Vol. 22, Special Issue 1, [Online], available at: https://www.abacademies.org/articles/Formation-of-theentrepreneurship-model-of-e-business-1528-2651-22-S1-337.pdf

10. Lake, P. and Behling, S. (2010), «E-businesses at risk: a look at the impact and control of e-business fraud», Issues in Information Systems, Vol. XI, No. 1, pp. 280-285.

11. Tan, G., «E-business and its advantages», [Online], available at: https://www.volusion.com/blog/e-businessadvantages/

12. Vitez, O., «E-business risks», [Online], available at: https://bizfluent.com/list-6188289-e-business-risks.html 
13. Wang, W.T., Wang, Y.S. and Liu, E.R. (2016), «The stickiness intention of group-buying websites: The integration of the commitment - trust theory and e-commerce success model», Information \& Management, No. 53 (5), pp. 625-642.

Ткачук В'ячеслав Олександрович - кандидат економічних наук, доцент кафедри цифрової економіки та міжнародних економічних відносин Державного університету «Житомирська політехніка». https://orcid.org/0000-0003-4898-956X.

Наукові інтереси:

- цифрова трансформація бізнес-процесів;

- хмарні сервіси в бізнесі.

E-mail: tkachuk.viacheslav@gmail.com.

Мельник Тетяна Юріївна - кандидат економічних наук, доцент, доцент кафедри цифрової економіки та міжнародних економічних відносин Державного університету «Житомирська політехніка».

https://orcid.org/0000-0002-1743-0264.

Наукові інтереси:

- аналітичне забезпечення системи управління суб’єкта господарювання;

- управління бізнес-процесами в умовах цифровізації економіки.

E-mail: melnyktanya09@gmail.com.

Богоявленська Юлія В'ячеславівна - кандидат економічних наук, доцент, доцент кафедри цифрової економіки та міжнародних економічних відносин Державного університету «Житомирська політехніка».

https://orcid.org/0000-0003-4101-7127.

Наукові інтереси:

- управління міжнародними проєктами та грантрайтинг;

- стратегія і тактика ведення переговорів.

E-mail: yubogoyavlenska@gmail.com.

Результати дослідження отримані у процесі виконання проєкту 618270-EPP-1-2020-1-LT-EPPKA2-CBНЕ-JP «Діджиталізація економіки як елемент стійкого розвитку України і Таджикистану» (2020-2023).

Стаття надійшла до редакції 04.10.2021. 